\title{
Border Security Problems in the Waters of the Natuna Islands: Between National Boundaries and Illegal Fishing
}

\author{
Fauzan ${ }^{1}$ \\ Department of International Relations ${ }^{1}$ \\ Universitas Pembangunan Nasional "Veteran" Yogyakarta, Indonesia ${ }^{1}$ \\ fauzan@upnyk.ac.id 1 \\ Kamarulnizam Abdullah² \\ College of Law, Government and International Studies ${ }^{2}$ \\ Universiti Utara Malaysia, Malaysia² \\ kamarulnizam@uum.edu.my² \\ Mohammad Zaki Ahmad 3 \\ College of Law, Government and International Studies ${ }^{3}$ \\ Universiti Utara Malaysia, Malaysia ${ }^{3}$ \\ zaki.ahmad@uum.edu.my³
}

\begin{abstract}
ABSTRAK
Natuna atau yang lebih dikenal dengan sebutan Kepulauan Natuna merupakan salah satu wilayah perbatasan di Indonesia yang memiliki problem yang kompleks. Sebagai wilayah kepulauan yang berbatasan dengan Malaysia dan Vietnam, Kepulauan Natuna juga berada di kawasan Laut China Selatan yang merupakan hot spot sengketa wilayah di Asia Timur. Tulisan ini akan membahas mengenai konsep keamanan perbatasan dan masalah keamanan perbatasan di perairan Kepulauan Natuna. Dalam tulisan ini, penulis berpendapat bahwa masalah batas maritim ZEE Indonesia di wilayah perairan Kepulauan Natuna dengan negara Malaysia dan Vietnam perlu segera diselesaikan, karena selain berkaitan dengan kedaulatan, kejelasan batas ZEE dengan negara tetangga akan berkaitan dengan pengelolaan sumber daya alam yang terkandung di wilayah perairan tersebut. Kondisi ini semakin rumit ketika China dengan nine-dashed line-nya telah memunculkan permasalahan overlapping claim di wilayah perairan Natuna. Selain itu, ketidakjelasan batas maritim tersebut digunakan pihak-pihak tertentu untuk melakukan aktivitas illegal fishing di wilayah perairan yang masih menjadi sengketa dengan negara tetangga.
\end{abstract}

Kata kunci: perbatasan, limology, keamanan perbatasan, batas maritim, illegal fishing 


\section{ABSTRACT}

Natuna or better known as the Natuna Islands is one of the border areas in Indonesia that has complex problems. As a cluster of islands bordering Indonesia with Malaysia and Vietnam, the Natuna Islands are also located in the South China Sea region, which is a regional dispute hot spot in East Asia. This paper will discuss the concept of border security and border security issues in the waters of the Natuna Islands. In this paper, the authors argue that the problem of the Indonesian EEZ maritime boundary in the Natuna Islands territorial waters with Malaysia and Vietnam needs to be immediately resolved, because in addition to sovereignty, the precision of the EEZ boundary with neighboring countries will be related to the management of natural resources contained in the particular territorial waters. This condition is increasingly complicated when China with its nine-dashed line has raised problems of overlapping claims in the Natuna waters. In addition, the obscurity of maritime boundaries is used by certain parties to carry out illegal fishing in the maritime areas currently being disputed by the neighboring countries.

Keywords: border, limology, border security, maritime boundary, illegal fishing

\section{Introduction}

Indonesia is the largest archipelagic state in the world consisting of 17,508 islands (Mabes TNI, 2007: 1), with a coastline of $108,000 \mathrm{~km}$, and an area of waters reaching 3,110,000 km2 (Madu, Loy, Nugraha \& Fauzan, 2010). Two-thirds of Indonesia's territory is sea. Indonesia's geographical position is between two oceans, namely the Indian Ocean and the Pacific Ocean, which geopolitically and geostrategically enable Indonesia to play an important role in both the region and globally. The territory of Indonesia has maritime borders with 10 countries, namely India, Thailand, Malaysia, Singapore, Vietnam, Philippines, Republic of Palau, Australia, Timor Leste, and Papua New Guinea. As for land areas, Indonesia is directly adjacent to three countries, namely Malaysia, Papua New Guinea, and Timor Leste with a total land border line reaching 2,914.1 km (Batara \& Sukadis, 2010).

In addition, the vastness of Indonesia's territory bordering with a number of countries can create problems and trans-boundary violations. Many cross-border violations that occur in Indonesia's border areas include illegal immigrant, human trafficking, illegal fishing, illegal logging, narcotics smuggling, oil smuggling, illegal surveys, and so on. In addition to cross-border violations that occur in the border region, the Indonesian 
border region still leaves overlapping maritime territorial claims with a number of neighboring countries.

Among the Indonesian border regions, the Natuna Islands waters region is one of the border areas in Indonesia that has maritime boundaries with Malaysia and Vietnam. Geographically, the Natuna Islands are in the northernmost region and are bordered by the waters of the South China Sea. Although Indonesia is not directly involved in disputes in the South China Sea, Indonesia has included the geo-strategic considerations of the South China Sea as one of the main issues related to Indonesian maritime policy. Indonesia is not one of the countries involved in the demands of the Spratly Islands, but also involves the Indonesian Exclusive Economic Zone (EEZ). The position of the Natuna Islands is very strategic in terms of both economy and defense, because it is located on the main route of international shipping. In the waters around the Natuna Islands there are also often illegal fishing activities by foreign fishing vessels.

The problems above show that the issue of border security is still a serious concern for the Indonesian government, because it involves the integrity of state sovereignty. Border security involves not only activities around the maritime border area but also on the boundary line. This article is intended to first, explain the concept of border security, secondly describe the problem of Indonesia's maritime boundary in the Natuna region, thirdly describe the problem of illegal fishing in the Natuna Islands waters and how to challenge border security issues in the Natuna waters. The scope of this study covered the problems during President Susilo Bambang Yudhoyono's terms. The scope of this study was the accidents/problems that occurred between 2008 and 2014.

\section{Understanding the Concept of Border Security}

Border and border security have always been crucial and strategic issues for a country. The border is a line that separates regions where the state can carry out its sovereignty in full. The border not only separates the territory owned by the state, but also can ensure the security of each country. In the context of a nation, borders are a basic element of the nation's identity (security), but in the context of a country, borders can be seen as an aspect of state security practices, or security functions (Laitinen, 2003). In the context of Indonesia, the border here can be interpreted as a borderline or a borderland. According to Law No. 26 of 2007 concerning Spatial Planning and Government Regulation (PP) No. 26 of 2008 concerning National Regional Spatial Planning (RTRWN), the definition of border area is a district/city area which is geographically and demographically bordered by neighboring countries and or the high seas. Whereas according to Law No. 43 of 2008 concerning the State Territory, the state border area is a part of the territory of the country which is located on the side of the boundary of the state and other countries. In the case of state 
borders on land, the border area is located in a sub-district facing the neighboring country.

Until now there is not any clear and comprehensive definition of the concept of border security. Not many experts explicitly provide and explain the definition of the concept of border security. The debate focused more on the concept of security itself. Therefore, to facilitate understanding of the conceptual framework of the position of border security concepts in the context of security studies, Buzan's framework of analysis on the concept of security in maintaining national interests and sovereignty can be used to explain the framework (Buzan, 2005). The concept of border security is among the two interactions of schools of thinking, namely traditional security groups and non-traditional security groups. Traditional security groups tend to limit the concept of security (de-securitization) and focus on what is referred to (referent object), namely sovereignty and state identity. Meanwhile non-traditional security groups tend to expand the concept of security (securitization) and have a very broad expanse of security (security landscape) about what is meant by security problems. Buzan's opinion on security is reinforced by Michael E. Brown's opinion by describing the differences in these security groups. The traditional group defines security issues as a security search activity by the state and competition between countries to achieve security. The security landscape according to this group is basically a problem between countries (interstate problems). Whereas according to non-traditional groups, the landscape declared by traditional groups is insufficient and must include intra-state security problems and cross-national security problems (transnational security problems). Brown argues that there needs to be an understanding of the issues of security, namely the problem of violent conflict originating from military and non-military factors, and the need to understand the security arena, whether interstate, intrastate and transnational (Brown, 2003; Keliat, 2009).

The concept of border borders is closely related to the concept of national security and the use of force by state officials to ensure regional security and sovereignty. The border area is considered as a natural location for securing the sovereignty of a country, so a number of special institutions such as the military, immigration, customs, police and so on needed to be stationed there, especially to deal with sources of threats and hazards around the country's borders. Border security is a complex concept, covering aspects of the military, economy, politics, environment and so on. In more general terms, border security is understood as the safety of life support systems and the absence of threats to people's lives and their activities in the border region (Kolossov, 2006). In the perspective of a Limology (border study), it is important to identify who is responsible for border security and what is the subject of threats to national borders. 
According to Nelson (2010), border security is included in a larger category than the term often referred to as homeland security. In the most basic sense, border security:

"... includes safeguarding a state's land, water, and water domains; deterring threats along these borders; and securing all points of entry, which are locations such as seaports, airports, and and border crossings, where officials are stationed to oversee the legal entry and exit of persons and merchandise" (Nelson, 2010)

According to Nelson, border security has three main functions, namely: detection, interdiction and deterrence. Detection is done by identifying border crossers (humans and goods) and classifying potential threats. Interdiction is done by, for example, placing border security agencies or placing a number of electronic technologies in the form of sensors and scanners to help improve the efficiency of border control. Interdiction is more related to how to prepare products of legislation and management activities in border areas. While deterrence is done by placing a number of obstacles along the border line to prevent unwanted cross-border mobility, for example by building walls along the border, placing barbed wire or installing other preventive technologies (Nelson, 2010).

Border security involves managing the flow of people, vehicles or transportation equipment, and other tangible items that cross the boundaries of a country. This concept can be applied in a variety of different topographic environments, both land and sea, and various threats on the border. The forms of threats that often occur at the border can be violations of sovereignty, illegal human migration, illegal smuggling of goods, human trafficking, illegal fishing, and so on. Besides the concept of border security, there is a concept of border control which is also often used in border security issues. According to Andreas (2003), the purpose of border control is to prevent the entry of clandestine transnational actors (CTA), which are interpreted as non-state actors operating beyond national borders in violation of state law and those who avoid law enforcement efforts (Andreas, 2003).

Meanwhile, Tholen (2010) compared the old "classic border controls" with "new border controls" (see Table 1 below). In this shift, less attention is paid to the physical lines of territorial borders as compared to the overall border space, from visa applications to surveillance of our daily lives. This new type of border control has led to a multiplication of boundaries and actors. Instead of being a single boundary line, border control in western countries can be illustrated by the "concentric circle model" (Tholen, 2010). The European Union, for example, has a four-tier border security model in the Schengen Agreement: 1) actions in third countries, 2) cross-border cooperation among member states, 3 ) border 
checks and monitoring on EU external borders, and 4) internal measures within EU. In other words, travelers and immigrants cross various borders before reaching their final destination (Heiskanen, 2014).

\begin{tabular}{|c|c|c|c|}
\hline & Border Guard & Border Control & Border Security \\
\hline Modus Operandi & Reaction & Pre-action & Prevention \\
\hline Location & Borderline & Border zone & Border zone, Cyberspace \\
\hline Focus of Control & Territory & Flows/people & Flows, Data subject \\
\hline $\begin{array}{l}\text { Moments of } \\
\text { Control }\end{array}$ & Single & Multiple & Contiuous \\
\hline Actors & Military & Law enforcement & Security apparatus \\
\hline Technology & Surveillance & Identity/biometrics & Data management \\
\hline Thread & Military & Migration & $\begin{array}{l}\text { Transboundary } \\
\text { Terrorism }\end{array}$ \\
\hline $\begin{array}{ll}\text { Idea } & \text { of } \\
\text { Goverment }\end{array}$ & Guard/segregation & Surveillance & Governance \\
\hline
\end{tabular}

Table 1: Transformation of Borders from Line to Space (Markus Heiskanen, 2014, Kawakubo, 2017), modified by author

Border control itself is becoming more sophisticated than ever before. Although the idea of a "closed" border never vanished from the traditional landscapes of geopolitics, new systems of border security have been developing since $9 / 11$. They have tended to introduce high-tech mechanisms into the field of border control (Kawakubo, 2017).

In the context of this article, the authors provide the definition of border security as the absence of all forms of threats and potential threats and disturbances to a country's borders and border areas in the forms of both military threats and nonmilitary threats. Included in the concept of border security is the precision of the boundaries of a country and other countries. Threats to a country's borders can be in the form of over-lapping claims of border areas with neighboring countries or involving several countries in a region, while the threats to the border area can be illegal activities that occur in the border area of a country or in an area that is still a dispute between two or more countries. In the case of maritime boundaries, for example, transnational crimes such as illegal fishing, transshipment, and smuggling are often carried out in a dispute area to avoid the supervision of a country's border patrol officers.

Therefore, border/boundary delimitation is still important for a country, because border delimitation provides clarity and certainty to all countries. Maritime border delimitation will provide clarity of the status of the region for maritime users and help minimize the risk of frictions and conflicts by eliminating a source of conflict both 
bilaterally and multilaterally. The lack of maritime border delimitation can often lead to the persistence of extensive overlapping claims over maritime jurisdiction, and this situation tends to exacerbate relations among countries having maritime borders (Schofield, 2011). In this context, the delimitation of Indonesia's borders in the Natuna waters with neighboring countries becomes important and urgent to be resolved immediately.

\section{The Geography of Natuna}

Natuna is a group of Indonesian islands located in the South China Sea and bordering maritime areas with Malaysia and Vietnam. Geographically, the Natuna Islands region is located at positions $1^{\circ} 16^{\prime}-7^{\circ} 19^{\prime}$ North Latitude and $105^{\circ} 00^{\prime}-110^{\circ} 00^{\prime}$ East Longitude. The area of Natuna Regency is $264,198.37 \mathrm{~km}^{2}$ where most of it consists of waters, covering an area of $262,197.07 \mathrm{~km}^{2}$ and the rest of the islands in the form of lands covering an area of 2,001.3 $\mathrm{km}^{2}$. As an island cluster, Natuna consists of 154 islands in Natuna Regency, with 27 inhabited islands and most islands (127 islands) uninhabited (Natuna Dalam Angka, 2015).

Bunguran Island and Serasan Island are the largest islands in the Natuna Islands. The islands consist of two clusters, namely: the Natuna Island cluster, comprising Bunguran, Sedanau, Midai, Laut Islands, and Tiga Island, and Serasan Island cluster, comprising Serasan, Subi, and Subi Kecil Islands.

The Natuna territory borders with other territories: (i) to the north with South China Sea (Vietnam); (ii) to the south with the Bintan area; (iii) to the west with Malay Peninsula; and (iv) to the east with South China Sea (Serawak, Malaysia).

The Natuna Islands region also has seven outermost islands which borders with the waters of neighboring countries (Malaysia and Vietnam). These islands are (i) Tokong Boro Island, (ii) Semiun Island, (iii) Sebetul Island, (iv) Senua Island, (v) Sekatung Island, (vi) Subi Kecil Island and (vii) Kepala Island. These seven outer islands are mostly uninhabited (see the Table 2 below). 
Border Security Problems in the Waters of the Natuna Islands: Between National Boundaries and Illegal Fishing

\begin{tabular}{|c|c|c|c|c|c|}
\hline No & $\begin{array}{l}\text { Name of the } \\
\text { Islands }\end{array}$ & Coordinates & $\begin{array}{ll}\text { Points } & \text { of } \\
\text { reference }\end{array}$ & $\begin{array}{l}\text { Bordering } \\
\text { Countries }\end{array}$ & Population \\
\hline 1 & Tokong Boro & $\begin{array}{l}04^{\circ} 04^{\prime} 01^{\prime \prime} \mathrm{NL} \\
107^{\circ} 26^{\prime} 09^{\prime \prime} \\
\mathrm{EL}\end{array}$ & $\begin{array}{l}\text { No. TD. } 028 \\
\text { No. TR. } 028\end{array}$ & Malaysia & Uninhabitated \\
\hline 2 & Semiun & $\begin{array}{l}04^{\circ} 31^{\prime} 09^{\prime \prime} \mathrm{NL} \\
107^{\circ} 43^{\prime} 17^{\prime \prime} \\
\mathrm{EL}\end{array}$ & $\begin{array}{l}\text { No. TD. } 029 \\
\text { No. TR. } 029\end{array}$ & $\begin{array}{l}\text { Malaysia } \\
\text { \&Vietnam }\end{array}$ & Uninhabitated \\
\hline 3 & Sebetul & $\begin{array}{l}04042^{\prime} 25^{\prime \prime} \mathrm{NL} \\
107054^{\prime} 20^{\prime \prime} \\
\mathrm{EL}\end{array}$ & $\begin{array}{l}\text { No. TD 030A } \\
\text { No. TR 030A }\end{array}$ & Vietnam & Uninhabitated \\
\hline 4 & Sekatung & $\begin{array}{l}04^{0} 47^{\prime} 38^{\prime \prime} \mathrm{NL} \\
108^{\circ} 00^{\prime} 39^{\prime \prime} \mathrm{EL}\end{array}$ & $\begin{array}{l}\text { No. TD 030B } \\
\text { No. TR } 030\end{array}$ & Vietnam & Inhabitated \\
\hline 5 & Senua & $\begin{array}{l}04^{\circ} 00^{\prime} 48^{\prime \prime} \mathrm{NL} \\
108^{\circ} 25^{\prime} 04^{\prime \prime} \\
\mathrm{EL}\end{array}$ & $\begin{array}{l}\text { No. TD } 031 \\
\text { No. TR } 031\end{array}$ & Malaysia & Uninhabitated \\
\hline 6 & Subi Kecil & $\begin{array}{l}03^{\circ} 01^{\prime} 51^{\prime \prime} \mathrm{NL} \\
108^{\circ} 54^{\prime} 52^{\prime \prime} \\
\mathrm{EL}\end{array}$ & $\begin{array}{l}\text { No. TD } 032 \\
\text { No. TR } 032\end{array}$ & Malaysia & Inhabitated \\
\hline 7 & Kepala & $\begin{array}{l}02^{\circ} 38^{\prime} 43^{\prime \prime} \mathrm{BL} \\
109^{\circ} 10^{\prime} 04^{\prime \prime} \\
\mathrm{EL}\end{array}$ & $\begin{array}{l}\text { No. TD } 033 \\
\text { No. TR } 033\end{array}$ & Malaysia & Uninhabitated \\
\hline
\end{tabular}

Table 2, The Outermost Small Islands in the Natuna Islands Region (KKP, 2009)

NL : North Latitude

EL : East Longitude

The table above shows the outermost small islands in the Natuna Territory. Of the seven islands, only two islands are inhabited. They are Sekatung island and Subi Kecil island. The position of the outermost islands is important to determine the base points to draw the maritime borderlines of the territorial seas, continental shelves, and EEZ.

The position and situation of the Natuna Islands have attracted attention, because it is located in the South China Sea region which is an international trade route and has become an area of dispute for several countries in the region. It has long been crossed by shipping and commercial lines that grow and connect among countries in Southeast Asia and East Asia (Wibisono, 2014).

\section{Maritime Boundary Issues}

In the territorial waters of the Natuna Islands, Indonesia has national borders with two countries, namely Malaysia and Vietnam, although recently there are unilateral demands from China over some parts of the Natuna Islands and the South China Sea. Indonesia in two directions has entered into the Continental Shelf border agreement in the South China Sea with Malaysia and Vietnam, while the EEZ limits with Malaysia and Vietnam are still under negotiation. 
Indonesian demands for territorial waters in the north of Natuna and the South China Sea have been based on agreements and laws, both international law and national law, including (i) UNCLOS 1982 article 2; (ii) Law No. 6 of 1996 concerning Indonesian waters; (iii) Government Regulation No. 37 of 2008 concerning Amendment to Government Regulation No. 38 of 2002 concerning Coordinate Lists of Indonesian Islands Baseline Points; (iv) Law No. 5 of 1983 concerning the Exclusive Economic Zone; and (v) Law No. 43 of 2008 concerning State Territory.

\subsection{EEZ problems with Vietnam}

There are two maritime boundaries between Indonesia and Vietnam in the waters of the South China Sea, namely the boundary of the Continental Shelf and EEZ. The two countries' continental shelf boundaries were agreed by Indonesia and Vietnam through negotiations on the Continental Shelf boundary between Indonesia and Vietnam on June 26, 2003, and Indonesia and Vietnam are currently negotiating the EEZ limit.

The settlement of the borders of the continental shelf of Indonesia with Vietnam which began in 1978 to 2003 and through a long and tough process basically provided a justification for Indonesia from several aspects, namely: (i) the recognition of boundaries and continental shelf between the two countries that has guaranteed legal certainty; (ii) the distribution of fair continental shelf areas in accordance with applicable international laws; (iii) the ease of efforts to monitor and enforce the sovereign rights of the state in the waters of the continental shelf; (iv) the legal recognition by the Vietnamese government over the outermost islands of the Natuna region facing Vietnam; and ( $v$ ) the strengthened position of Indonesia's maritime boundary claims in the South China Sea, especially against China (Wiranto, 2015: 115).

So far, the settlement of the EEZ boundary between Indonesia and Vietnam has still not been achieved. The negotiations on the EEZ of the two new countries began on May 14-21, 2010 in Hanoi, Vietnam. Indonesian and Vietnamese delegates have held negotiations to determine the EEZ's maritime boundary between the two countries. Between 2010-2016, Indonesian and Vietnamese EEZ negotiations have been held in eight rounds. The final negotiations, the 8th Technical Negotiations on the Indonesia-Vietnam EEZ Limitation have been held in Bali, March 22-24, 2016. The next Technical Settlement is planned to take place in Vietnam in April or May 2016 (Foreign Affais, 2016).

The map below shows the overlaps in the waters of the South China Sea. The figure shows the continental shelf boundaries that have been agreed between Indonesia and Vietnam and the demands of the Indonesian EEZ. 


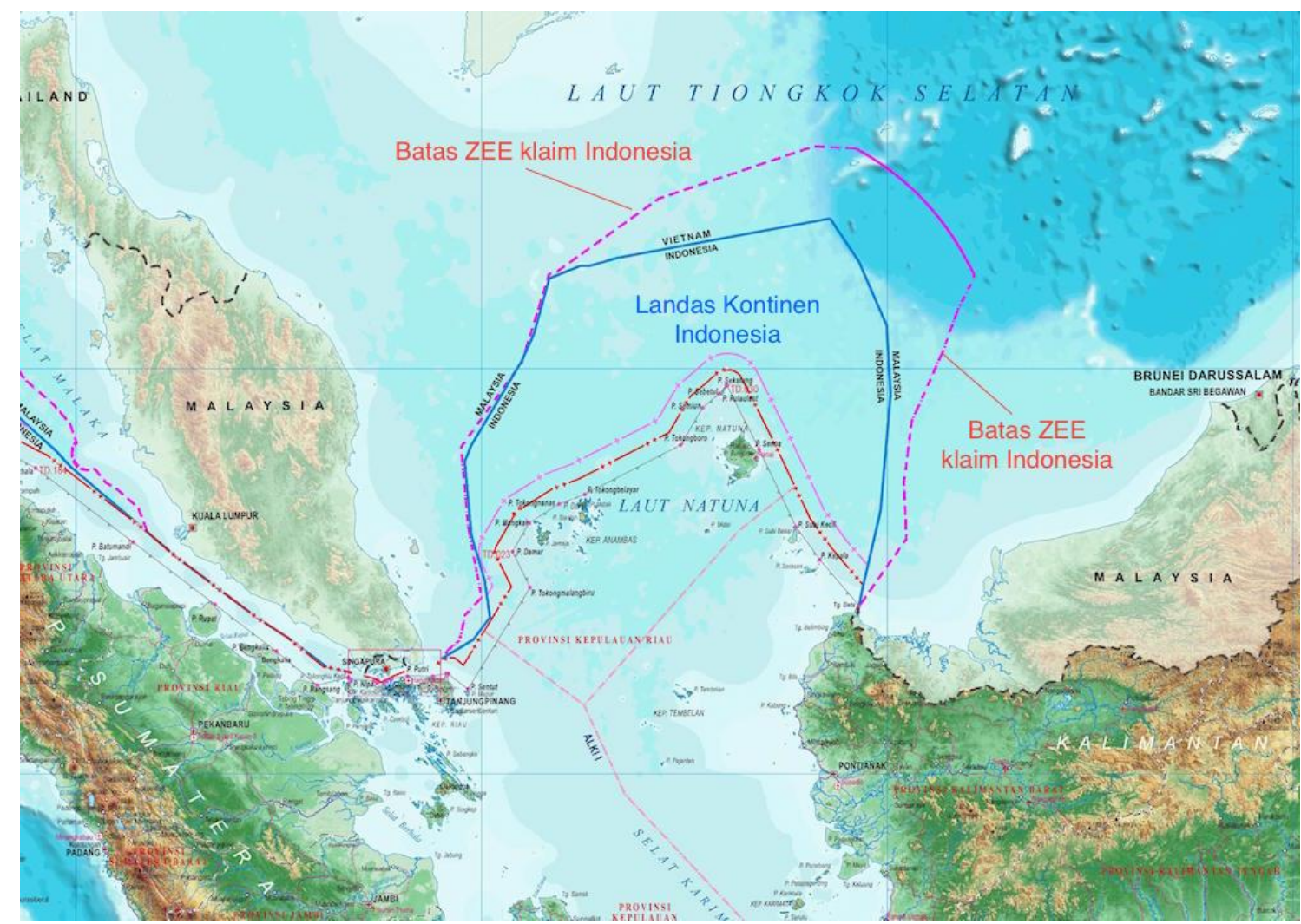

Figure 1, Map of Overlaps in North Natuna Waters (South China Sea), (http://madeandi.staff.ugm.ac.id/2016/03/28/berebut-ikan-di-laut-tion China-selatan/)

\subsection{EEZ problems with Malaysia}

In addition to having overlapping maritime boundaries with Vietnam, Indonesia also has maritime boundary problems with Malaysia in several segments, especially regarding the EEZ limits of the two countries. The boundary of the Continental Shelf in the waters of the South China Sea has been agreed between Indonesia and Malaysia in 1969, while the EEZ boundary between the two countries in this region has not yet been agreed. Malaysia has the view that the continental shelf boundary and EEZ in the South China Sea are the same, whereas Indonesia has a different view, that the Continental Shelf boundary and EEZ boundary are not the same. This difference of views is the obstacle in resolving EEZ boundary negotiations in the South China Sea (Tabloid Diplomasi, 2010: 35).

Indonesia still has three unsettled maritime boundary segments with Malaysia, namely in the Straits of Melaka, the South China Sea, and the Sulawesi Sea. This maritime boundary includes the territorial sea, continental shelf and EEZ. The sea borders of the territory of Indonesia with Malaysia in the Straits of Melaka have been agreed through an agreement between Indonesia and Malaysia concerning the 
Application of the Territorial Border Territories of the Two Countries in the Straits of Melaka which were signed on March 17, 1970 and ratified by Law No. 2 of 1971. The boundaries of the Indonesian and Malaysian Continental Shelf in the Natuna Sea on the west and east have been agreed through the Agreement between Indonesia and Malaysia concerning the Settlement of Border Continents between the Two Countries on October 27, 1969 and endorsed by Presidential Decree No. 89 of 1969 concerning the Border Approval of the Indonesian Continental Shelf with Malaysia (Presidential Decree No. 89 of 1969). Meanwhile the boundary of the Continental Shelf between Indonesia and Malaysia and Thailand in the northern part of the Melaka Strait was agreed on December 17, 1971 and ratified through Presidential Decree No. 20 of 1972 concerning Ratification of the Agreements of Indonesia, Malaysia and Thailand concerning the Establishment of the Continental Border Line in the North of Straits of Melaka (Presidential Decree No. 20 of 1972).

The map below shows several segments of the Indonesian and Malaysian maritime boundaries that still need to be resolved and agreed upon between the two countries. For segments in the South China Sea, Indonesia and Malaysia need to agree on the EEZ limit.

\section{Indonesia - Malaysia Maritime Border Segments}

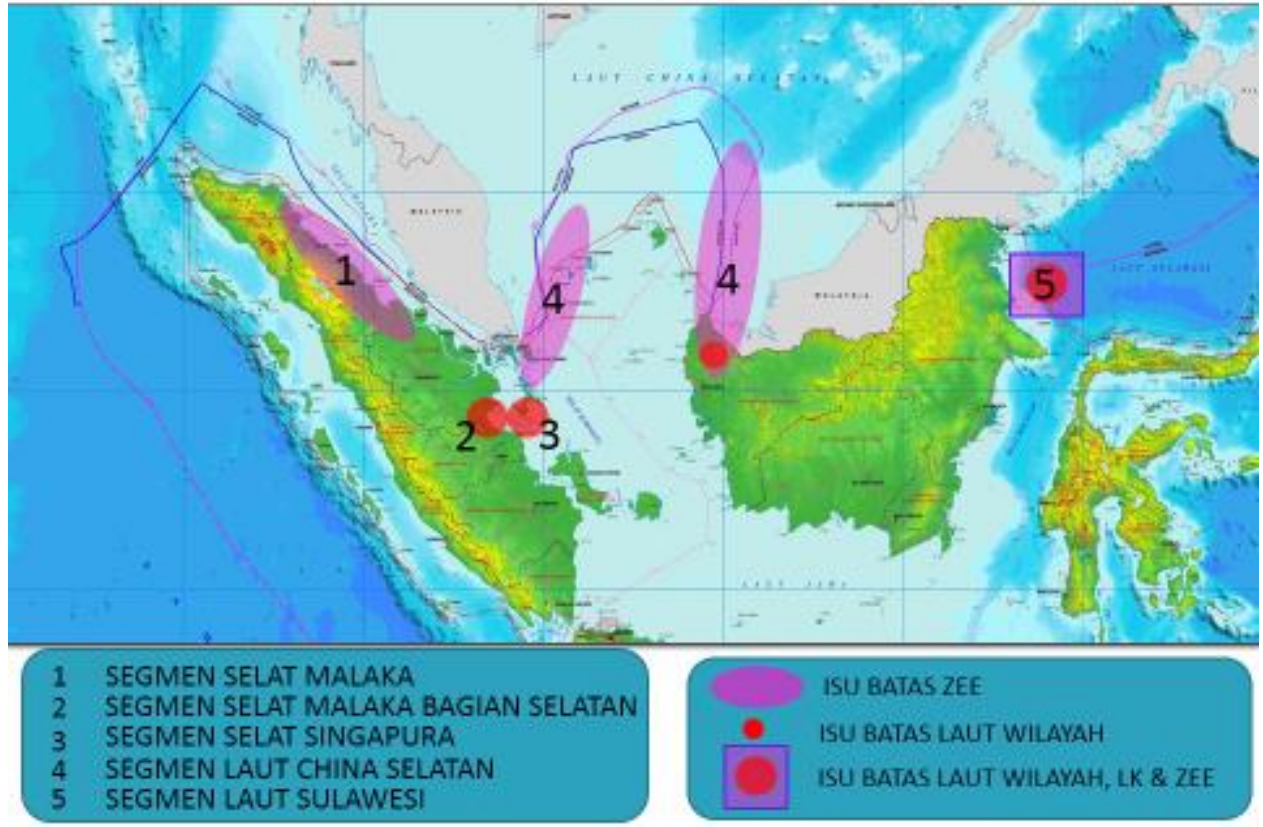

Figure 2, Map of Indonesia - Malaysia Maritime Border Segments (Foreign Affairs, 2014) 
The map above shows the Indonesia-Malaysia maritime boundaries that are still negotiated on its boundaries, namely (i) Territorial sea in the Sulawesi Sea segment, South China Sea (around Tanjung Datu), Eastern Singapore Strait (Bintan-Johor), South Malacca Strait ; (ii) Continental Shelf in the Sulawesi Sea segment; and (iii) Exclusive Economic Zone (EEZ) in the Malacca Strait segment.

Indonesia and Malasyia have been negotiating the maritime boundaries of the two countries at the Technical Level since 2015. The most recent negotiation was the 29th Technical Negotiations on Maritime Boundary Determination that had been held in Jakarta on 16-17 March 2016. To accelerate the process of resolving Indonesia's maritime boundaries with Malaysia, the Indonesian government has appointed the Special Envoy of the President of the Republic of Indonesia as a partner to PM Malaysia's Special Envoy to discuss recommendations for resolving the two countries' maritime boundaries by considering various aspects, including legal and technical aspects. The Special Envoys of the two countries have held the Second Meeting between Special Envoys in Bali on 11-12 February 2016 (Foreign Affairs, 2016).

Despite the current dynamics of the development of maritime boundaries between Indonesia and Malaysia in the Natuna Islands waters region, it is interesting to look at the opinions of some Malaysian scholars regarding Natuna's status. In an article written by Malaysian scholars and published in the MStar newspaper media titled "Kepulauan Natuna: 'Bergeografikan Malaysia' Berdaulatkan Indonesia" the history of Natuna in the Malaysian scholar version is elaborated (mstar online, 2013). In the article it is stated that Natuna's history cannot be separated from the influence of countries in the Malay Land. The highlight of the history of the government and the early population of the Malays in Natuna clearly shows that the Natuna Islands have closer relations with countries in the Malay Land compared to the kingdoms of the Indonesian archipelago or the Dutch colonizers based in Batavia (Jakarta) (mstar online, 2013). Based on this fact, it can be said that Indonesia has ruled Natuna Island for 56 years without objection from Malaysia since 1956. Therefore, according to the article it is difficult at this time for Malaysia to reassert sovereignty over the Natuna Islands even if based on geographic and historical facts, the Natuna Islands had strong ties with countries in the Malay Peninsula.

\subsection{The Problem of China's Nine Dashed Lines}

In addition to the overlapping problems with Malaysia and Vietnam, Indonesia has recently faced the problem of overlapping of the ZEE region and the continental shelf with unilateral Chinese claims. Until now, in the South China Sea, Indonesia has maritime boundaries with only Malaysia and Vietnam. So far Jakarta has never negotiated maritime boundaries with Beijing. 
China began demanding the South China Sea region and Natuna waters when the country issued its map in 1947. It began during the Nationalist Government of Chiang Kai-Sek in 1947 which had established nine interrupted marks covering almost the entire South China Sea (Wiranto, 2015). Then this was reaffirmed by Zhou En-Lai in 1951, but China did not explain the aspects of the law on the demands of the region. In fact, China's demands on the South China Sea region are based on the nine dots line and if it is reconstructed, it will cut the agreed continental shelf boundary with Malaysia and Vietnam, and cut the demands of the Indonesian EEZ boundary (Majalah Tannas, 2013). China's demand for a portion of Natuna waters is more influenced by name and history than anything else.

But in its development, China consistently carried out activities that were quite provocative by placing the country's ships to escort their fishing vessels, to the south and entering the Indonesian EEZ. Until the end of 2015, China was also increasingly intensive and assertive in the South China Sea. China has several regional demands with countries around the South China Sea, including with Indonesia regarding the nine dashed lines that cover the waters around the Natuna islands on China's map in 1992. Although until now, China has never been able to explain explicitly to Indonesia about his demands for the nine dashed lines.

China's unilateral demands on the entire waters of the South China Sea and the cutting off Indonesia's EEZ zones are major diplomatic problems. Even though so far Indonesia is not included as one of the countries involved in overlapping in the South China Sea, Jakarta has firmly rejected Beijing's demands for its nine dashed lines. China's attitude which seems to "hold back" and as if it does not have border problems with Indonesia, needs to be a concern for Indonesia (Majalah Tannas, 2013).

The fact in the waters around Natuna shows that from May to June 2010 and March 2013, Chinese armed ships have taken provocative actions in the Natuna Sea waters against Indonesian Maritime and Fisheries Ministry Supervisory ships carrying out inspections and safeguards on Chinese fishing boats fishing in Indonesian waters. This shows the attitude of China's provocation that some of the waters of the Natuna Sea are included within China's nine-dashed lines, being considered as the traditional fishing area for Chinese fishermen (Catra: Majalah Setjen Wantannas, 2016). 


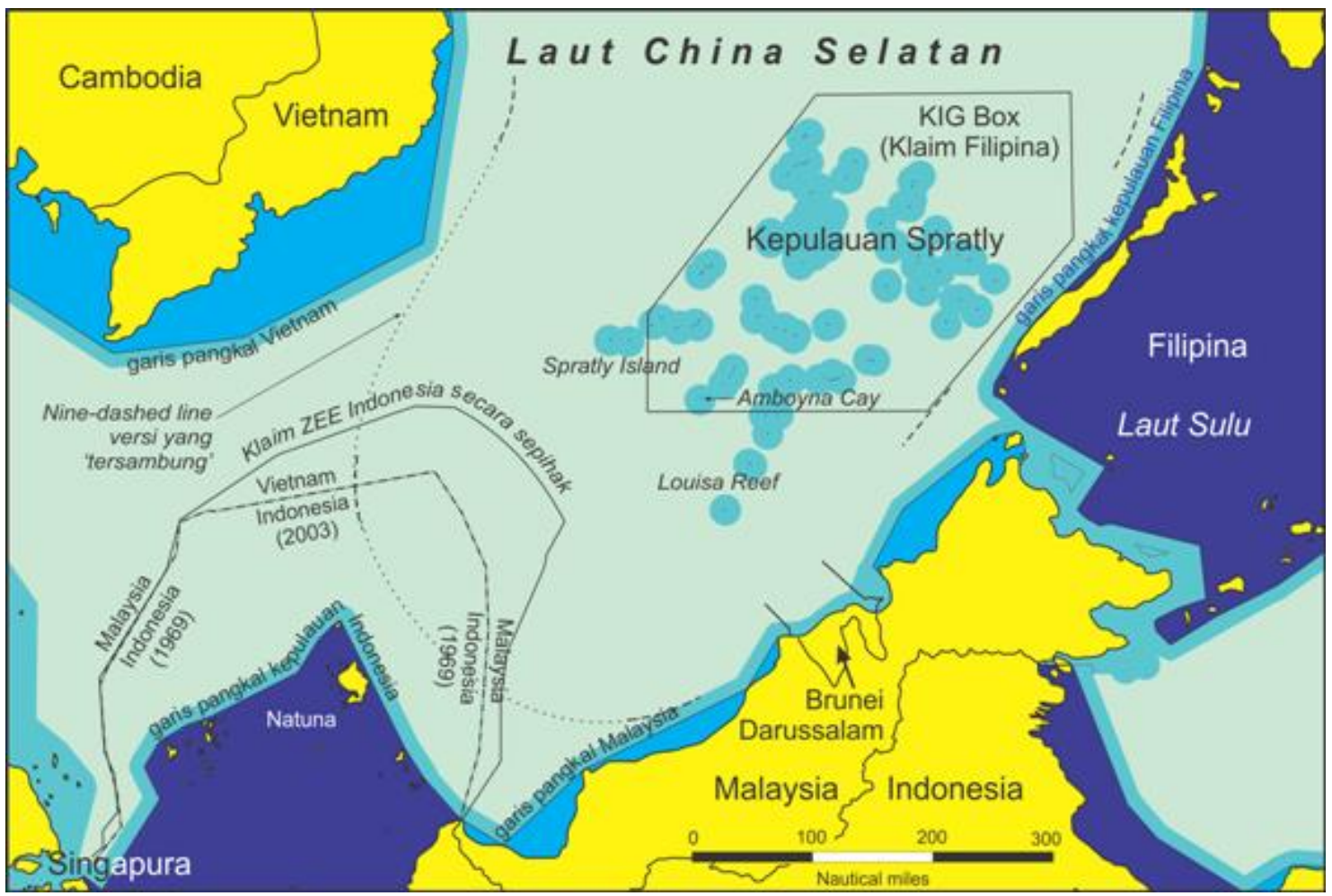

Figure 3, Map of Overlaps in the waters of the South China Sea (Catra: Majalah Setjen Wantannas, 2016).

Based on the national law and the international law including UNCLOS 1982, the region is part of the territory of Indonesia, and other countries have no right to enter the region let alone explore its natural products, as practiced by Chinese fishermen escorted by Coast Guard officers. The actions of the Chinese fishing boats and ships seemed to pressure Indonesia to recognize the territories demanded by China's nine dashed lines.

\section{Problems with Border Security of the Natuna Islands}

In addition to the potential for overlapping regional claims, the obscurity of the Natuna Islands' maritime boundaries with neighboring countries is also a frequent cause of incidents of territorial violations by foreign fishermen fishing in Natuna waters which are famous for their rich natural resources and quality fish species, and has high commercial value (Anindya, 2013). The potential of the Natuna Islands marine wealth is estimated at more than one million tons every year (Anindya, 2013; Aktual online, 2015). However, almost every day there are illegal fishing cases by foreign fishing vessels in the territorial waters of the Natuna Islands (interview Satgas PSDKP). 
The media often reports the presence of a large number of foreign fishing vessels (FFV) from Malaysia, Thailand, Vietnam and China, and Indonesian fishing vessels (IFV) that illegally fish in the EEZ area around the waters of the Natuna Islands. There is a significant number of illegal fishing cases by foreign fishing vessels in these waters. Data from the Marine and Fisheries Resources Supervision (PSDKP), Ministry of Fisheries and Marine Affairs (KKP) in 2007-2014 shows that the number of Vietnamese fishing vessels arrested for illegal fishing around the Natuna Islands waters reached 417 ships. The majority of Vietnamese fishing boats detained did not have documents to catch fish in Indonesian waters (Jakarta Greater Online, 2014). Foreign vessels may catch fish in Indonesian waters if they have documents that are known as Fisheries Business Permits (FBP) and Fishing Licenses (FL) which are legalized by the Indonesian government. Apart from Vietnam, Thailand and Malaysian fishing boats also often violate the territorial waters of the Natuna Islands to catch fish illegally. From 2007 to 2014, the PSDKP KKP vessels had arrested 103 Thai vessels, and captured 81 fishing vessels registered in Malaysia. When carrying out fishing activities in the waters of the Natuna Islands, the foreign fishing boats used Indonesian flags to mislead patrol officers, and they also counterfeited the Indonesian citizenships for their crew.

In terms of economic implications, illegal fishing activities threaten not only the source of income of local fishermen but also sources of state financial income. For example, a local newspaper media reported "if night falls in Natuna waters glittering lights from thousands of foreign fishing boats esemble a city, and they fish with a ship being capable of catching 40 tons of fish." In general, illegal fishing activities which often occur in the waters of the Natuna Islands are increasingly alarming. Based on data released by the Ministry of Maritime Affairs and Fisheries of the Republic of Indonesia, state losses due to illegal fishing activities are estimated at Rp. 300 trillion every year (detik online, 2015).

In addition to the economic implications, incidents of detention of foreign fishing vessels and crew members also influenced relations and triggered tensions between the Indonesian government and other countries. The problem occurred on June 23, 2010, in which the detention of Chinese fishing boats by Indonesian PSDKP officers forced the Chinese government to send two heavily armed patrol boats to free their citizens and the ship from the PSDKP officers (Supriyanto, 2012; Dupont \& Baker, 2013). A similar case occurred on March 26, 2013, when a Chinese fishing boat with a gastric number 58081 and a capacity of $150 \mathrm{GT}$ (gross tonnage) was detained by a ship from the 001 Hiu PSDKP patrol. However, it was forcefully released after the Chinese patrol ship threatened to shoot the PSDKP patrol boat if the Chinese fishing boat and its crew were not released. 
In addition to regional violations and illegal fishing incidents involving foreign fishing vessels, the territorial waters of the Natuna Islands are also an area of overlapping maritime territorial claims with neighboring countries, namely Vietnam, Malaysia and China. Indonesia and Vietnam for example, have not reached an agreement in determining the EEZ limits of the two countries (BNPP, 2011). The negotiation of the continental shelf between Indonesia and Vietnam has been started since June 1978 and reached an agreement at the negotiations in Hanoi, Vietnam on June 26, 2003, and ratified by the Indonesian government with Law No. 18/2007 dated March 15, 2007. However, the settlement of the EEZ boundary between Indonesia and Vietnam has not yet succeeded in reaching an agreement, although several negotiations have been held between the two countries.

In this case, Indonesia does not consider the border issue with Vietnam a big issue because the threat from China over the Natuna Islands waters is considered more serious (Dollah, 2012: 67). China began demanding the South China Sea region and Natuna waters when the country issued its map in 1947. Subsequently in 1976, China stated that the entire South China Sea was Chinese territory. In its development, China has increasingly dared to show aggressive and assertive actions in the South China Sea in order to maintain regional demands and sovereignty over the islands and coral reefs in the region (Supriyanto, 2012; Dupont \& Baker, 2013). Even China's demands for the waters of the South China Sea also include the Natuna waters which are within the nine dashed lines. Several times cases of regional violations have occurred in Natuna waters involving Chinese military ships and Chinese fishing vessels (see the Table 3 below).

\begin{tabular}{|c|c|c|c|c|}
\hline \multirow[b]{2}{*}{ No } & \multicolumn{2}{|l|}{ Cases } & \multicolumn{2}{|c|}{ The vessels of countries involved } \\
\hline & Time & Details & $\begin{array}{l}\text { Chinese } \\
\text { vessels }\end{array}$ & Indonesian vessels \\
\hline 1 & $\begin{array}{l}20 \text { June } \\
2009\end{array}$ & $\begin{array}{l}\text { Illegal fishing by a Chinese fishing } \\
\text { vessel }\end{array}$ & & $\begin{array}{lll}\begin{array}{l}\text { PSDKP } \\
\text { vessel }\end{array} & \text { KKP } & \text { patrol } \\
\end{array}$ \\
\hline 2 & $\begin{array}{l}13 \text { May } \\
2010\end{array}$ & $\begin{array}{l}\text { Violation of EEZ border by A Chinese } \\
\text { vessel }\end{array}$ & Yuzheng 302 & KRI SRE-386 \\
\hline 3 & $\begin{array}{l}15 \text { May } \\
2010\end{array}$ & Provacation by Chinese vessel & Yuzheng 301 & $\begin{array}{l}\text { KKP HIU } 003 \text { \& KKP HIU } \\
004\end{array}$ \\
\hline 4 & $\begin{array}{l}22 \text { June } \\
2010\end{array}$ & $\begin{array}{l}\text { Interdiction of adhoc by a Chinese } \\
\text { vessel }\end{array}$ & $\begin{array}{l}\text { Yuzheng } 303 \\
\& \text { Yuzheng } 311\end{array}$ & KKP HIU 005 \\
\hline 5 & $\begin{array}{l}23 \text { June } \\
2010\end{array}$ & Provocation of a Chinese vessel & $\begin{array}{l}\text { Yuzheng } 303 \\
\text { \& Yuzheng } 311\end{array}$ & $\begin{array}{l}\text { KKP HIU } 009 \text { \& KKP HIU } \\
\text { 010, KRI Ahmad Yani \& } \\
\text { KRI Teuku Umar }\end{array}$ \\
\hline 6 & $\begin{array}{l}26 \text { March } \\
2013\end{array}$ & $\begin{array}{l}\text { Interdiction of HENRIKHAN process } \\
\text { and communication signal jamming } \\
\text { by a Chinese vessel }\end{array}$ & $\begin{array}{l}\text { Yuzheng } 310 \\
\text { \& Nanfeng }\end{array}$ & KKP HIMA 001 \\
\hline
\end{tabular}

Table 3, Violations by Chinese Army and Chinese Fishermen Ships in the Waters of the Natuna Islands (Prabowo, 2013: 6).

HENRIKHAN (stopping, checking, carrying and holding) is a series of actions in the context of escorting and empowering the law in the fisheries sector which includes efforts to stop, inspect 
and carry vessels suspected or reasonably suspected of committing acts of crime in the fisheries management area (FMA) of the Republic of Indonesia.

Although Indonesia is not directly involved in territorial disputes in the South China Sea, Indonesia has included geostrategic considerations in the territorial waters, not only as one of the locations of the world's major shipping lanes but also as a basis for the demands of its maritime region. This is because the disputed region in the South China Sea, which involves several countries, also encompasses a portion of Indonesia's EEZ region, especially in the waters of the Natuna Islands.

In addition to the above problems, the Natuna region often also faces the problem of smuggling goods, especially on Serasan Island, which is located adjacent to the Sarawak region of Malasyia. At least every two days there are five fishing boats departing from the Batu Ampar area, East Serasan area to the Sematan region, Sarawak Malaysia to sell fish from fishermen's catches in Natuna waters. This catch is a category A and B fish which has a high selling value and is exchanged for goods needed by the Serasan community, especially subsidized goods borne by the Malaysian government such as liquid gas, rice, sugar, milk, gas, cooking oil, etc (research on Serasan Island, 2016). The quality of fish can be categorized into several grades, namely grade A, B, C and D. Grade A fish have the following characteristics: (i) color of fresh fish meat; (ii) clean, bright and prominent eyes; (iii) normal skin, clean and bright colors; (iv) the texture of fish meat is hard, chewy and elastic; and ( $v$ ) the condition of the fish is good and intact, whereas grade $B$ fish have the following characteristics: (i) red fish flesh color; (ii) clean, bright and prominent eyes; (iii) normal, clean and slightly mucous skin; and (iv) no fish damage (whole). Grade $A$ and $B$ fish are sold in whole and fresh form (not frozen in ice chests). Whereas grade $C$ and $D$ fish are processed fish before being sold / exported and in the form of frozen.

The issue and border problems in the waters of the Natuna Islands above are quite alarming and a serious concern for the Indonesian government. In addition to the problem of EEZ border settlement with several countries, there is also the problem of illegal fishing (illegal, unreported, unregulated/IUU fishing) in the Natuna waters. During the administration of Susilo Bambang Yudhoyono (SBY, the Minister of Maritime Freddy Numberi made a policy to sink illegal fishing vessels. However the policy was not applied very often because SBY's principle of foreign policy was 'thousand friends zero enemy" (Sihombing, 2014).

\section{Conclusion}

The border is a manifestation of the sovereignty of a country's territory. The settlement of Indonesian maritime boundaries is influenced and determined by the 
historical, political and relations processes of neighboring countries which are then adjusted to the rules or provisions of national laws and international laws. The issue of borders in the waters of the strong Natuna Islands has three aspects, namely sovereignty, security and prosperity. This is because it relates to state borders, border security, and natural resource wealth in the border region. Therefore, the management of border areas requires a basis and an approach that are supported by integrated regulations and institutions.

The territorial waters of the Natuna Islands have borders with Malaysia and Vietnam and have overlaps with China in the waters of the South China Sea. The limits of the continental shelf have been agreed by Malaysia and Vietnam, but the EEZ limits are still in the process of negotiations. The position of Natuna waters is very strategic because it is in the shipping and international trade routes, has a large natural resource wealth, in the form of hydrocarbons and fisheries, and is located around the disputed territorial waters of the South China Sea involving several countries in the region. The territorial waters of the Natuna Islands have challenges related to border security issues, namely the unresolved maritime boundaries with neighboring countries and illegal fishing by foreign fishermen, as well as cases of smuggling of goods from the Sarawak region. Therefore, in the future the government needs to increase the security of the border region in the waters of the Natuna Islands. Cooperation in border management through both applying border diplomacy and securing the border waters around the Natuna region needs to be done effectively to reduce the emergence of conflicts with regional countries.

\section{Acknowledgement}

This article was supported by UUM-PBIT No. S/O: 12876.

\section{References}

\section{Books}

Batara, A. \& Sukadis, B. (ed.). (2007) Reformasi Manajemen Perbatasan di NegaraNegara Transisi Demokrasi. Jakarta: DCAF-LESPERSSI.

BNPP RI (2015) Rencana Induk Pengelolaan Perbatasan Negara Tahun 2015-2019, Jakarta: Badan Nasional Pengelola Perbatasan.

Brown, M. E. ed. (2003) Grave New World: Security Challenges in the $21^{\text {st }}$ Century, Washington: Georgetown University Press, p. 305-325. 
Buzan, B. et. al. (1998) Security: A New Framework for Analysis, Colorado: Lynne Rienner Publisher.

Heiskanen, M. (2014) Border Games: From Duel to Russian Roulette at the Border, in Borders, Fences, and Walls: State of Insecurity? ed. Elisabeth Vallet. New York: Ashgate, p. 68.

Mabes TNI (2007) Buku Petunjuk Pelaksanaan TNI Tentang Operasi Pengamanan Perbatasan, Jakarta: Mabes TNI, p. 1.

Madu, L., Loy, N., Nugraha, A., and Fauzan. (2012) Mengelola Perbatasan Indonesia di Dunia Tanpa Batas: Isu, Permasalahan dan Pilihan Kebijakan. Yogyakarta: Graha Ilmu, p. 5.

Payan, T. (2006) The Three US-Mexico Borders War: Drugs, Immigration and Homeland Security, Westport: Praeger Security International.

Schofield, C. (2011) The Delimitation of Maritime Boundaries: An Incomplete, in The Ashgate Research Companion to Border Studies, ed. Doris Wastl-Walter, England: Ashgate Publishing Limited, p. 665-681.

$\underline{\text { Journals }}$

Andreas, P. (2003) Redrawing the Line: Borders and Security in Twenty-first Century. International Security, Vol. 28, No. 2, Fall, p. 78-111.

Dollah, R. dan Wan Shawaluddin Wan Hassan, (2012) Cabaran dan Pengurusan Perbatasan Maritim Indonesia: Pengajaran Kepada Malaysia, Jati, 17, December, p. 67.

Dupont, A. and Baker, C. G. (2014) East Asia's Maritime Disputes: Fishing in Troubled Waters, The Washington Quarterly, Vol. 37, No. 1, Spring, p. 85-86.

Kawakubo, F. (2017) The Transformation of Border Security Practices from Fixed Borders to New Modalities and Privatization: From the Perspective of Critical Border Studies, Eurasia Border Review, Vol. 8, No. 1, Fall, p. 8-9.

Keliat, M. (2009) Keamanan Maritim dan Implikasi Kebijakannya Bagi Indonesia". Jurnal IImu Sosial dan IImu Politik, Vol. 13, No. 1. July, p. 111-129.

Kolossov, V. (2006) Theoritcal Limology: Postmodern Analytical Approaches, Diogenes, 53 (11), p. 13.

Laitinen, K. (2003) "Geopolitics of the Northern Dimensions: a Critical View of Border Studies," Geopolitics, Vol. 8, No. 1, p. 30. 
Nelson, R. (2010) "Border Security in a Time of Transformation: Two International Case Studies - Poland and India", A Report of the CSIS Homeland Security \& Counter terrorism Program, Europe Program and South Asia Program, July, 5-10.

Prabowo, E. (2013) Pembangunan Kekuatan Maritim China dan Pengaruhnya Terhadap Kepentingan Indonesia, Majalah Tannas, 96 Edition, p. 6.

Supriyanto, R. A. (2015) Indonesia's Natuna Islands: Next Flashpoint in the South China Sea? Making Waves, 28 (2), 28 February, p. 4-7.

Tholen, B. (2010) The Changing Border: Developments and Risks in Border Control Management of Western Countries, International Review of Administrative Sciences $76(2)$.

Wibisono, S. C., (2014) Natuna Archeology: Maritime Corridors in the Waters of the South China Sea, Kalpataru: Majalah Arkeologi, 23 (2), p. 81-150, November.

Wiranto, S. (2015) Resolusi Konflik Menghadapi Sengketa Laut China Selatan: Dari Perspektif Hukum Internasional (p. 115), Yogyakarta: Leutikaprio.

-------- (2012) Penataan Pengamanan Wilayah Maritim Guna Memelihara Stabilitas Keamanan dalam Rangka Menjaga Kedaulatan NKRI, Jurnal Kajian Lemhannas RI, Edisi 14, December.

\section{Dissertations}

Anindya, A. W. (2013) "Strategi dan Kebijakan Membangun Daya Saing Perikanan Kabupaten Natuna", PhD Dissertation, Sekolah Pascasarjana, Institut Pertanian Bogor, 2013, p. 1-7.

\section{Legal Documents}

Government Regulation No. 26/2008.

Law No. 2/1971.

Law No. 6/1973.

Law No. 7/1973.

Law No. 17/1095.

Law No. 34/2004.

Law No. 18/2007. 
Law No. $26 / 2007$

Law No. 43/2008.

Presidential Decree No. 89/1969.

Presidential Decree No. 42/1971.

Presidential Decree No. 20/1972.

Presidential Decree No. 21/1982.

Presidential Regulation No. 178/2014.

Internet Sources

--------, Pesan untuk Cina dengan Pemberian Nama Laut Natuna Utara, https://tirto.id/pesan-untuk-cina-dengan-pemberian-nama-laut-natuna-utara-csSL, accessed on 9bOctober 2016.

--------, "Pencurian Ikan di Natuna Didominasi Oleh Kapal Vietnam" http://www.aktual.co/sosial/133252pencurian-ikan-di-natuna-didominasi-olehkapal-vietnam, accessed on 15 October 2015.

--------, "Kronologi Penangkapan Tiga Petugas DKP", http://regional.kompas.com/read/2010/08/15/16192881/Kronologi.Penangkapan.Ti ga.Petugas.DKP, accessed on 10 November 2014.

--------, "Gesekan di Laut China Selatan", http://jakartagreater.com/historiagesekan-di-laut-china-selatan, accessed on 15 Desember 2014.

--------, "Menteri Susi: Seharusnya RI jadi Negara Maju Karena Laut yang Kaya" http://finance.detik.com/read/2015/02/05/113541/2824349/4/menteri-susiseharusnya-ri-jadi-negara-maju-karena-laut-yang-kaya, accessed on 17 March 2016

--------, "Kepulauan Natuna: 'Bergeografikan Malaysia' Berdaulatkan Indonesia," http://www.mstar.com.my/lain-lain/rencana/2013/12/07/kepulauan-natunabergeografikan-malaysia-berdaulatkan-indonesia/, accessed on 25 April 2013.

--------, "Permasalahan di Perbatasan RI", Tabloid Diplomasi, Februari 2013, http://www.tabloiddiplomasi.org/previous-isuue/183-diplomasi-februari2013/1598-permasalahan-di-perbatasan-ri.html., accessed On 5 August 2014. 